\title{
Community-Based Health Insurance and Associated Factors in North-Western Ethiopia. The Case of Bahir Dar City
}

This article was published in the following Dove Press journal: International Journal of General Medicine

\author{
Getasew Mulat Bantie (D) \\ Ashenafi Abate Woya $\mathbb{D}^{2}$ \\ Birhanu Mengist Zewdie ${ }^{3}$ \\ 'Public Health Department, Community \\ Health Faculty, Alkan Health Science \\ Business and Technology College, Bahir \\ Dar, Ethiopia; ${ }^{2}$ Statistics Department, \\ Science College, Bahir Dar University, \\ Bahir Dar, Ethiopia; ${ }^{3}$ Geography and \\ Environmental Studies Department, \\ Social Sciences College, Bahir Dar \\ University, Bahir Dar, Ethiopia
}

Background: Health insurance provides access to health care with financial risk protection. Knowledge and attitude have been found to influence enrolment in community-based health insurance, which avoids catastrophic health-care expenditure. However, knowledge and attitude levels towards health insurance are not well studied. The objective of this study was to determine the knowledge and attitude level of the informal workers of the Bahir Dar city towards community-based health insurance.

Methods: A community-based cross-sectional study was conducted with systematically selected 335 informal workers. We conducted structured face-to-face interviews using a newly developed and validated questionnaire. The collected data were coded and then entered into Epi data and exported to SPSS software for analysis. Logistic regression analysis was used to identify potential associations between the study variables.

Results: Out of 325 informal workers, $51 \%$ of them had good knowledge of communitybased health insurance, while $56 \%$ of participants had a favorable attitude towards community-based health insurance. Being single $(\mathrm{AOR}=3.4,95 \% \mathrm{CI} ; 1.3,9.0)$, daily laborer $(\mathrm{AOR}=2.73,95 \% \mathrm{CI} ; 1.36,5.48)$, attending secondary education $(\mathrm{AOR}=0.29 ; 95 \% \mathrm{CI}$ : $0.12,0.71)$, and obtaining information from television $(\mathrm{AOR}=0.31,95 \% \mathrm{CI} ; 0.14,0.71)$ were found to be statistically associated with knowledge. While being single $(\mathrm{AOR}=0.23$, 95\% CI: $0.08,0.67)$, married ( $\mathrm{AOR}=0.29,95 \% \mathrm{CI}: 0.11,0.73)$, daily laborer $(\mathrm{AOR}=2.84$, $95 \% \mathrm{CI}: 1.37 .5 .88)$, getting information from television $(\mathrm{AOR}=3.09,95 \% \mathrm{CI}: 1.37,6.93)$ and family $(\mathrm{AOR}=2.63,95 \% \mathrm{CI}: 1.23,5.61)$ were found to be statistically associated with the attitude towards community-based health insurance.

Conclusion: The knowledge and attitude level of the informal workers towards communitybased health insurance were low. Therefore, community-based health insurance should be promoted to ensure the accessibility of health care to all.

Keywords: community-based health insurance, knowledge, attitude, informal worker, Bahir Dar city, Ethiopia

\section{Introduction}

In the context of low-income countries, low understanding, and knowledge of the notion of health insurance had been contributing to a low level of enrolment to voluntary health insurance schemes. ${ }^{1}$ During sensitization and awareness creation for health insurance interventions, the focus is usually on the amount of premium that potential enrollees are expected to pay. Less focus was given on explaining concepts such as solidarity, risk pooling, moral hazard, and adverse selection which is a limitation. ${ }^{2}$
Correspondence: Ashenafi Abate Woya Department of Biostatistics, Bahir Dar University, Bahir Dar City, Ethiopia Tel +25I-9|2389679

Email ashu.abate@gmail.com
International Journal of General Medicine 2020:13 1207-1217 
Community-Based Health Insurance (CBHI) is one of the strategies which is designed to achieve the Sustainable Development Goals. ${ }^{1,2}$ Among this universal health coverage, including financial risk protection, making essential medicines and vaccines accessible, effective and affordable to all are among the goals to be attained by 2030 . $^{3,4}$ Nowadays, 800 million people are exposed to catastrophic health expenditure. For instance, in 2010 one-tenth of the household's budget was allotted to cover health services but in 2000 it was $9.7 \% .^{5}$ In the lower socioeconomic group of the society, mainly in Africa, the expense for medical expenditure results in immense financial barriers and worsens the life of households. ${ }^{6}$

One in four families across forty developing countries like Ethiopia resorted to borrowing or selling assets to afford health care, which points towards that the current health-care financing strategies in low- and middle-income countries are failing to protect many households from potential economic hardship. ${ }^{7}$ The introduction of health insurance schemes aims at supporting countries to reduce direct payments for health care. ${ }^{8}$

Almost in all developing countries, community-based health insurance systems are derived partly from a need to provide financial protection against unexpected health-care costs and to enhance access to modern health care. ${ }^{9}$ generally, health insurance coverage in Sub-Saharan countries is low, which accounts for $10 \%$ of the population. ${ }^{3}$

Previously, the Ethiopian health-care policy which was based on out-of-pocket health-care policy resulted in low health-care service utilization and poor health condition. ${ }^{10}$ Following this, Ethiopia endorsed has endorsed the community-based health insurance in 2011 within 13 pilot districts in Amhara, Oromia, Southern Nations Nationalities, and Tigray regions, ${ }^{11}$ and has been working on to expand throughout the nation. ${ }^{12}$ The communitybased health insurance scheme gives many benefit packages of health-care service utilization at public health facilities. ${ }^{12}$ That scheme is said to be community-based health insurance or CBHI. CBHI is health insurance that pools members' premium payments into a collective fund, which is managed by the members, and covers basic health-care costs at local health centers when a member is sick. The insurance is even acceptable at hospitals when a member is referred by the lower-level health facilities. ${ }^{13}$ It appears to be the most appropriate insurance model for employees of informal sectors and households of rural areas since their income is unpredictable. ${ }^{14}$ In Ethiopia, initially in 2011, to get service the government determined the premium contribution fee to be180 Ethiopian birr, ${ }^{15}$ which is now revised to 240 Ethiopian Birr per household per annum. ${ }^{16}$ However, the scheme excludes some of the health-care packages like getting treatment abroad, kidney dialysis, and implanting artificial teeth and plastic surgery. ${ }^{12}$

Knowing the level of knowledge and attitude of Bahir Dar city informal workers towards the community-based health insurance is very important to correct the poor awareness and knowledge level of the informal workers on community-based health insurance, and to avert the perceptions and negative attitudes of the city's informal workers to expand and implement the community-based health insurance in the coming years in this study area. Previous studies focused on health-care access, and in addition use of a specific geographic community were not linked with the knowledge and attitudes of the community in the adoption of a CBHI scheme. Therefore, the current study was designed to assess the knowledge and attitude of the informal workers towards community-based health insurance in Bahir Dar city.

\section{Methods \\ Study Design and Setting}

A community-based cross-sectional study was conducted from May 1st to 3rd June 2017 in the informal workers of Bahir Dar city, the capital city of Amhara National Regional State. In 2016, in the city, the number of informal workers were estimated to be about 220,943 individuals were informal workers. Of which, 145,720 were males.

\section{Sample Size Determination and Sampling Technique}

The sample size was determined using a single population proportion formula by taking a $95 \%$ confidence level, $5 \%$ level of precision, $80 \%$ of knowledge level, ${ }^{10}$ as well as $10 \%$ non-response. The sample size was determined by a single population proportion formula. $\frac{z^{2} \times \hat{p}(1-\hat{p})}{\epsilon^{2}}$ Substituted, $\mathrm{p}=0.8,=0.05 \mathrm{and}^{2} Z_{\alpha_{/ 2}}=1.96$. The required sample size was 246 . Add $10 \%$ non-response rate, and design effect 1.2 the sample size becomes 325 .

To get the expected sample size (325), the lists of the adult individuals in each of the nine sub-city were proportionally allocated using a systematic random sampling technique from each sub city's kebele registration book. 
Households were selected from each selected kebeles. Then, each adult from each selected household was interviewed. When more than one eligible adult is available in the selected household, the simple random sampling method was employed.

\section{Eligibility Criteria}

Informal workers of 18 years and older and who resided at least six months preceding the data collection period were recruited for the study. However, those who were seriously ill, unable to communicate, and/or refuse to participate were excluded to respect the declaration of Helsinki.

\section{Study Variables}

\section{Dependent Variable}

The magnitude of the community towards knowledge and attitude of $\mathrm{CBHI}$

\section{Independent Variables}

Socio-demographic variables: Age, sex, residence, occupation, religion, monthly income, and educational status

Behavioral factors: Medical checkup habit, culture, lifestyle

\section{Measurements and Data Collection}

We conducted structured face-to-face interviews using a newly developed and validated questionnaire. The questionnaire was developed by reviewing different kinds of literature. $4,9,14,15,17-20$ The questionnaire had socio-demographic, health, knowledge, and attitude assessing characteristics (attached as a supplementary material). The items of the questionnaire were dichotomous and multiple-choice type. The content validity of the questionnaire was approved by experts. It was first prepared in the English language and then translated into the local language (Amharic), and finally, it was retranslated back to English to maintain its consistency. Finally, the data were collected using the Amharic version questionnaire. A total of two days of rigorous training for enumerators and supervisors was given to assure the quality of the data. Similarly, before the actual data collection, data collectors and supervisors carried out role play practices and had field pre-test activities in five percent of the total sample size before the actual data collection. The data collectors and the supervisor were university graduate Bsc and MPH holders, respectively. During the data collection, every day, each questionnaire was examined for completeness and consistency by the supervisors and the principal investigator, and then pertinent feedbacks were given to the data collectors. The internal consistency (Cronbach alpha) level of the pretest of knowledge and attitude assessing characteristics was between 0.74 and 0.83 , respectively.

\section{Data Quality Assurance}

The principal investigator (PI) trained the data collectors and the project investigators, who supervised the data collectors on the goals of the project and on data quality. The enumerators and the project investigators carried out pre-test activities in five percent of the total sample size before the actual data collection. At the end of every data collection day, the project investigators examined each questionnaire and gave pertinent feedback to the enumerators.

\section{Operational Definitions}

Health Insurance

Is a payment package that is designed to satisfy the healthrelated demands of the people. It operates in the form of small contributions, which can be made monthly, quarterly, or annually to the facilitator of the scheme, and any health need that arises form members within the scope of the insurance to cover.

\section{Informal Workers}

In this study, informal workers were considered as those individuals who were not employed in governmental, nongovernmental, or private institutions and had no monthly income to be paid.

A respondent was considered as having good knowledge about community-based health insurance when he/ she correctly responded mean and above score of the eleven knowledge assessing questions. Otherwise, he/she was considered as having poor knowledge.

A respondent was considered as having a favorable attitude towards the community-based health insurance when he/she correctly responded mean and above score of the ten attitude assessing questions. Otherwise, he/she was considered as having an unfavorable attitude.

\section{Data Analysis}

Data were coded, entered, and cleaned using Epi Data version 3.1 and exported to SPSS version 21.0 statistical software for analysis. Descriptive summaries such as frequencies, mean and standard deviations were 
determined. Logistic regression analyses were carried out to identify significant variables. Before conducting multivariable analysis, model fitness and the presence of multicollinearity were assessed. The model fitness was checked by observing the difference of the $-2 \log$ likelihood ratio between the model with only the constant and with the factors. Multivariable analysis was computed out to identify independently significantly associated factors of dependent variables. The significance of each factor in the equation was also assessed by the wald statistics test at a significance level of $\mathrm{P}$-value $<0.05$.

\section{Results}

\section{Socio-}

\section{Demographic and Health-Related Characteristics of the Study Participants}

A total participants in this study, 325 of them returned their completed questionnaires yielding a response rate of $97.0 \%$. Almost half (50.8\%) of the respondents were male. One hundred-forty-four $(44.3 \%)$ of the participants completed college and above education. The average monthly income of participants was in the range of 1500-10,000 Ethiopian Birr. More than onethird (39.7\%) and $120(38.8 \%)$ of the participants were daily laborers and housewives, respectively. About 107 $(32.9 \%)$ of the study participants were feeling sick a month ahead of the data collection period. Also, twothird $(67.4 \%)$ of the study participants were worried about paying when they feel sick (Table 1).

\section{Knowledge Characteristics}

The vast majority that is 305 (93.8\%) of the respondents were aware of community-based health insurance. Their source of information was family, $152(46.8 \%)$; television, 89 (27.4\%); friends, 49 (15.1\%) and magazine, 35 (10.8\%), respectively. Taking the knowledge assessing questions into consideration, the composite score of the respondents having a good knowledge of CBHI was 51.4\% (Table 2).

\section{Attitude Characteristics}

Taking the ten attitude assessing questions into consideration, the composite score of the respondents having a favorable attitude towards community-based health insurance was about $55.7 \%$ (Table 3 ).

\section{Factors Associated with Knowledge on $\mathrm{CBHI}$}

On bivariate analysis, sex, age, educational status, marital status, occupation, and source of information were statistically associated with informal workers' knowledge status on the community-based health insurance, whereas in the multivariate analysis, age and sex did not show a significant association with knowledge status towards community-based health insurance.

For those informal workers who attended secondary education, the odds of good knowledge towards CBHI was $1.3(\mathrm{AOR}=1.29,95 \% \mathrm{CI}: 1.12,1.71)$ times higher compared to those who have no formal education attended. For those who have ever not married informal workers, the odds of good knowledge towards CBHI was 3.4 (AOR=3.436, 95\% CI: $1.30,9.02)$ times higher compared to those who were divorced. For those daily laborers, the odds of good knowledge towards CBHI was 2.7 (AOR=1.19, 95\% CI: 1.36, 5.48) times higher compared to those who were student and housewife. However, informal workers who got information from television, the odds of good knowledge towards $\mathrm{CBHI}$ was $69 \%(\mathrm{AOR}=0.31,95 \% \mathrm{CI}$; $0.14,0.71)$ times less compared to those who got information from friends (Table 4).

\section{Factors Associated with Attitude Towards CBHI}

On bivariate analysis, sex, educational status, marital status, occupation, age, and source of information were statistically associated with informal workers' attitude towards community-based health insurance, whereas in the multivariate analysis, age and sex did not show a significant association with attitude status towards community-based health insurance.

For those informal workers who attended secondary education, the odds of favorable attitude towards CBHI was $2.04(\mathrm{AOR}=2.04,95 \% \mathrm{CI}: 1.91,4.56)$ times higher compared to those who attended college and above. For those informal workers who have not ever married, the odds of favorable attitude towards CBHI was $77 \%$ (AOR $=0.23,95 \%$ CI: $0.08,0.67)$ times less compared to divorced informal workers. Similarly, for married informal workers, the odds of favorable attitude towards $\mathrm{CBHI}$ was $71 \%$ (AOR $=0.29,95 \% \mathrm{CI}: 0.01$, 0.73) times less compared to divorced informal workers. For those daily laborers, the odds of favorable 
Table I Socio-Demographic and Health-Related Characteristics

\begin{tabular}{|c|c|c|c|}
\hline Variables & Characteristics & Frequency & Percent \\
\hline \multirow[t]{2}{*}{ Sex } & Male & 165 & 50.8 \\
\hline & Female & 160 & 49.2 \\
\hline \multirow[t]{4}{*}{ Age } & $18-24$ & 37 & 11.4 \\
\hline & $25-32$ & 123 & 37.8 \\
\hline & $33-39$ & 85 & 26.2 \\
\hline & $\geq 40$ & 80 & 24.6 \\
\hline \multirow[t]{3}{*}{ Religion } & Orthodox & 267 & 82.2 \\
\hline & Muslim & 45 & 13.8 \\
\hline & Protestant & 13 & 4.0 \\
\hline \multirow[t]{5}{*}{ Educational status } & $\begin{array}{l}\text { No formal } \\
\text { education }\end{array}$ & 63 & 19.4 \\
\hline & $\begin{array}{l}\text { Primary } \\
\text { education }\end{array}$ & 60 & 18.5 \\
\hline & Secondary & 58 & 17.8 \\
\hline & education & & \\
\hline & $\begin{array}{l}\text { College and } \\
\text { above }\end{array}$ & 144 & 44.3 \\
\hline \multirow[t]{3}{*}{ Marital status } & Single & 92 & 28.3 \\
\hline & Married & 197 & 60.6 \\
\hline & Divorced & 36 & 11.1 \\
\hline \multirow[t]{4}{*}{ Occupation } & Merchant & 63 & 19.4 \\
\hline & Farmer & 7 & 2.1 \\
\hline & Daily laborer & 129 & 39.7 \\
\hline & Others ${ }^{\#}$ & 126 & 38.8 \\
\hline \multirow[t]{3}{*}{ Monthly income (birr) } & $<1500$ & 107 & 32.9 \\
\hline & $1500-10,000$ & 202 & 62.2 \\
\hline & $>10,000$ & 16 & 4.9 \\
\hline \multirow[t]{2}{*}{ History of previous illness } & Yes & 306 & 94 \\
\hline & No & 19 & 6 \\
\hline \multirow[t]{5}{*}{ Time to the last illness } & $\begin{array}{l}\text { Before one } \\
\text { month }\end{array}$ & & \\
\hline & $\begin{array}{l}\text { Before three } \\
\text { months }\end{array}$ & 91 & 28.0 \\
\hline & Three months & 108 & \\
\hline & I am not feeling & 19 & 5.8 \\
\hline & sick at all & & \\
\hline \multirow{5}{*}{$\begin{array}{l}\text { The measure took when they } \\
\text { feel sick }\end{array}$} & Go to doctor & 277 & 90.5 \\
\hline & Take herbal & 13 & 4.2 \\
\hline & Treat my self & 11 & 3.6 \\
\hline & Go to a religious & 5 & 1.6 \\
\hline & place & & \\
\hline \multirow[t]{3}{*}{ Need medical care in a year } & Once in a year & 223 & 68.6 \\
\hline & $\begin{array}{l}\text { Once in three } \\
\text { months }\end{array}$ & 69 & 21.2 \\
\hline & Once in six & 33 & 10.2 \\
\hline
\end{tabular}

(Continued)
Table I (Continued).

\begin{tabular}{|l|l|l|l|}
\hline $\begin{array}{l}\text { Have you ever been admitted } \\
\text { to the hospital }\end{array}$ & Yes & 203 & 62.5 \\
No & 122 & 37.5 \\
\hline Worry about paying when get & Yes & 219 & 67.4 \\
sick & No & 106 & 32.6 \\
\hline
\end{tabular}

Note: Other ${ }^{\#}$ (student, housewife).

attitude towards $\mathrm{CBHI}$ was $2.84(\mathrm{AOR}=2.84 ; 95 \% \mathrm{CI}$ : $1.37,5.88)$ towards $\mathrm{CBHI}$ compared to housewives and students.

For informal workers who got information from television, the odds of favorable attitude towards CBHI was about 3.1 (AOR=3.09, 95\% CI: 1.37, 6.93) times higher compared to those who got information from friends. Similarly, for those informal workers who got information from families, the odds of favorable attitude towards CBHI was about $2.6(\mathrm{AOR}=2.63,95 \%$ CI: $1.23,5.61)$ times higher compared to those who got friends (Table 5).

\section{Discussion}

The study revealed that $51.4 \%$ of the respondents had good knowledge of community-based health insurance. This finding was lower compared to the study finding from South Africa, 80.2\%. ${ }^{10}$ Whereas it was higher compared to the study from Cameron $25.6 \% .{ }^{17}$ The discrepancy might be due to variation in geographical location, time, social norms, lifestyles, and/or different socio-economic conditions, and health information dissemination. The other possible justification for this difference might be due to the variation in the variables used to measure the knowledge level of CBHI for the current study and the former studies. This shows that there is a discrepancy in awareness creation for residents from country to country due to different reasons. These could be due to low access to health education about the health insurance issue. This could also be due to the place where the study was done, religious aspect, social belief, low social media coverage, and many other reasons.

Moreover, about $56 \%$ of the study participants had a favorable attitude towards community-based health insurance. This finding was lower than the study findings of Tehulederie, Ethiopia ${ }^{18}$ This finding was higher than the studies conducted in south India, $40 \%,{ }^{20}$ and Nigeria, $52.5 \%{ }^{19}$ This difference might be attributed 
Table 2 Knowledge Assessing Characteristics of the Respondents

\begin{tabular}{|c|c|c|c|}
\hline Variables & Category & Frequency & Percent \\
\hline \multirow[t]{2}{*}{ Have you ever heard CBHI } & Yes & 272 & 83.7 \\
\hline & No & 53 & 16.3 \\
\hline \multirow[t]{4}{*}{ Source of information on $\mathrm{CBHI}$} & Family & 152 & 46.8 \\
\hline & Television & 89 & 27.4 \\
\hline & Friends & 49 & $|5|$. \\
\hline & Magazine & 35 & 10.8 \\
\hline \multirow[t]{2}{*}{ Are you aware of the benefits package of $\mathrm{CBHI}$} & Yes & 165 & 50.8 \\
\hline & No & 160 & 49.2 \\
\hline \multirow[t]{3}{*}{ The community-based health insurance scheme will pay for your medical expenses when you get sick } & True & 146 & 44.9 \\
\hline & False & 139 & 42.8 \\
\hline & $\begin{array}{l}\text { I am not } \\
\text { sure }\end{array}$ & 40 & 12.3 \\
\hline \multirow{3}{*}{$\begin{array}{l}\text { The } \mathrm{CBHI} \text { scheme will cover the health care services gained by the formally employed and not employed } \\
\text { households once joined to the } \mathrm{CBHI} \text { scheme }\end{array}$} & True & 148 & 45.5 \\
\hline & False & 84 & 25.8 \\
\hline & $\begin{array}{l}\text { I am not } \\
\text { sure }\end{array}$ & 93 & 28.6 \\
\hline \multirow{3}{*}{$\begin{array}{l}\text { Both the rich and the poor will receive proper healthcare of the same quality without catastrophic } \\
\text { medical cost when becoming a member of the } \mathrm{CBHI} \text { scheme }\end{array}$} & True & 202 & 62.2 \\
\hline & False & 50 & 15.4 \\
\hline & $\begin{array}{l}\text { I am not } \\
\text { sure }\end{array}$ & 73 & 22.5 \\
\hline \multirow{3}{*}{$\begin{array}{l}\text { The quality of healthcare services will be almost the same throughout the whole country once the } \\
\text { country implemented the community based-health insurance }\end{array}$} & True & 142 & 43.7 \\
\hline & False & 71 & 21.8 \\
\hline & $\begin{array}{l}\text { I am not } \\
\text { sure }\end{array}$ & 112 & 34.5 \\
\hline \multirow{3}{*}{$\begin{array}{l}\text { You will receive services from the referred contracted higher health facilities with no out of pocket money } \\
\text { when your health is needing a specialized health care setup. }\end{array}$} & True & 121 & 37.2 \\
\hline & False & 46 & 14.2 \\
\hline & $\begin{array}{l}\text { I am not } \\
\text { sure }\end{array}$ & 158 & 48.6 \\
\hline \multirow{3}{*}{$\begin{array}{l}\text { The community-based health insurance covers the cost of pharmaceutical care and diagnostic tests for } \\
\text { referred cases }\end{array}$} & True & 100 & 30.8 \\
\hline & False & 78 & 24.0 \\
\hline & $\begin{array}{l}\text { I am not } \\
\text { sure }\end{array}$ & 147 & 45.2 \\
\hline \multirow{3}{*}{$\begin{array}{l}\text { The community-based health insurance scheme excludes treatment abroad, kidney dialysis/treatments, } \\
\text { artificial teeth, and plastic surgery }\end{array}$} & True & 128 & 39.4 \\
\hline & False & 69 & 21.2 \\
\hline & $\begin{array}{l}\text { I am not } \\
\text { sure }\end{array}$ & 128 & 39.4 \\
\hline \multirow{3}{*}{$\begin{array}{l}\text { The community-based health insurance scheme pays for the services received from only governmental } \\
\text { health institutions }\end{array}$} & True & 48 & 14.8 \\
\hline & False & 121 & 37.2 \\
\hline & $\begin{array}{l}\text { I am not } \\
\text { sure }\end{array}$ & 156 & 48.0 \\
\hline \multirow[t]{3}{*}{ Allow people to have equal/fair access to skilled health professionals and/to finance for health care } & True & 192 & 59.1 \\
\hline & False & 52 & 16.0 \\
\hline & $\begin{array}{l}\text { I am not } \\
\text { sure }\end{array}$ & 81 & 24.9 \\
\hline
\end{tabular}


Table 3 Attitude Assessing Characteristics of the Respondents

\begin{tabular}{|c|c|c|c|}
\hline \multirow[t]{2}{*}{ Variables } & \multicolumn{3}{|l|}{ Category } \\
\hline & $\begin{array}{l}\text { Agree } \\
\text { N (\%) }\end{array}$ & $\begin{array}{l}\text { No } \\
\text { Opinion } \\
\text { N (\%) }\end{array}$ & $\begin{array}{l}\text { Disagree } \\
\text { N (\%) }\end{array}$ \\
\hline $\begin{array}{l}\text { Community based health insurance has the potential of on promoting healthcare seeking behavior from } \\
\text { modern health care institutions }\end{array}$ & $220(67.7)$ & $49(15.1)$ & $56(17.2)$ \\
\hline Community based health insurance protects from unaffordable healthcare expenditures & $270(83.1)$ & $16(4.9)$ & $39(12)$ \\
\hline Premium payment for community-based health insurance scheme is expensive & $5 I(15.7)$ & 38 ( 11.7$)$ & $\begin{array}{l}236 \\
(72.6)\end{array}$ \\
\hline Community-based health insurance is a means of collecting revenue (profit) to the government & $43(13.2)$ & $75(23.1)$ & $\begin{array}{l}207 \\
(63.7)\end{array}$ \\
\hline Community based health insurance scheme members receive low quality of services than non-members & $55(16.9)$ & $20(6.2)$ & $\begin{array}{l}250 \\
(76.9)\end{array}$ \\
\hline Mistreatment of patients by the health professionals is common for members than non-members & $53(16.3)$ & $77(23.7)$ & $195(60)$ \\
\hline I did not have trust in management and administration of community-based health insurance scheme & $108(33.2)$ & $5 I(15.7)$ & $\begin{array}{l}166 \\
(51.1)\end{array}$ \\
\hline Community-based health insurance is relevant only to promote health condition of the poor & $142(43.7)$ & $70(21.5)$ & $\begin{array}{l}113 \\
(34.8)\end{array}$ \\
\hline Health insurance is good to pool the risk of health expenditures within the sick and the healthy & $179(55.1)$ & $4 I(12.6)$ & $\begin{array}{l}105 \\
(32.3)\end{array}$ \\
\hline Health insurance should be advocated and scale up to improve the health condition of rural community & $234(72)$ & $20(6.2)$ & $71(21.8)$ \\
\hline
\end{tabular}

from the spectrum of the study population at which the former studies focused at the national level while the current study is confined only at the specific-segmented population (informal workers). The finding indicated that a bit more than a quarter of the respondents $(27.4 \%)$ got information from their family, which was lower than the study conducted in the Cameron littoral region of Douala, $61 \% .{ }^{17}$ This could be varied due to the variation in their educational status, poor communication within the family, and health system of the countries.

This study expressed that about two-thirds (67.4\%) of study participants were worried about making payments when they feel sick. This study finding is supported by other studies, almost all studies indicated that patients were worried about payments. ${ }^{22-24}$

The study showed that for respondents who had no formal education $(\mathrm{AOR}=129 ; 95 \% \mathrm{CI}: 1.12,1.71)$, got information from television $(\mathrm{AOR}=0.31,95 \% \mathrm{CI} ; 0.14$,
0.71), being single $(\mathrm{AOR}=3.4,95 \% \mathrm{CI} ; 1.3,9.0)$, and daily laborers $(\mathrm{AOR}=2.73 ; 95 \% \mathrm{CI}: 1.36,5.48)$ determine the status of knowledge while being single $(\mathrm{AOR}=0.23$; 95\% CI: 0.08, 0.67), married (AOR=0.29; 95\% CI: 0.11 , $0.73)$, daily laborer $(\mathrm{AOR}=2.84 ; 95 \% \mathrm{CI}: 1.37,5.88)$, and getting access to information from their families $(\mathrm{AOR}=2.63 ; 95 \% \mathrm{CI}: 1.23,5.61)$ were significantly associated with attitude towards the community-based health insurance, respectively.

The marital status of the respondents affects the knowledge and attitude level towards communitybased health insurance. This finding explicitly revealed that though the married and not married respondents had good knowledge, they had less chance to have a favorable attitude towards community-based health insurance. This finding is consistent with other study findings. $^{25,26}$ Moreover, occupational status of the respondents also affects the knowledge and attitude level towards community-based health insurance. 
Table 4 Factors Associated with Knowledge of Community-Based Health Insurance Among Bahir Dar City Informal Workers

\begin{tabular}{|c|c|c|c|c|}
\hline \multirow[t]{2}{*}{ Variables } & \multicolumn{2}{|c|}{ Knowledge of CBHI } & \multirow[t]{2}{*}{ COR $(95 \% \mathrm{Cl})$} & \multirow[t]{2}{*}{ AOR (95\% Cl) } \\
\hline & Poor & Good & & \\
\hline \multicolumn{5}{|l|}{ Sex } \\
\hline Male & 65 & 100 & 1.00 & 1.00 \\
\hline Female & 93 & 67 & $0.468(0.30,0.73)$ & $1.67(0.99,2.79)$ \\
\hline \multicolumn{5}{|l|}{ Education } \\
\hline No formal education & 35 & 28 & 1.00 & 1.00 \\
\hline Primary & 33 & 27 & $1.023(0.50,2.08)$ & $1.191(0.54,2.64)$ \\
\hline Secondary & 46 & 12 & $1.326(1.15,1.73)$ & $1.29(1.12,1.71)^{*}$ \\
\hline College and above & 44 & 100 & $2.84 I(1.54,5.23)$ & $1.64(0.74,3.63)$ \\
\hline \multicolumn{5}{|l|}{ Marital status } \\
\hline Single & 35 & 57 & $4.234(1.82,9.82)$ & $3.436(1.30,9.02) *$ \\
\hline Married & 97 & 100 & $2.680(1.23,5.85)$ & $2.357(0.97,5.7 \mathrm{I})$ \\
\hline Divorced & 26 & 10 & 1.00 & 1.00 \\
\hline \multicolumn{5}{|l|}{ Occupation } \\
\hline Merchant & 38 & 25 & $1.10(0.59,2.06)$ & $1.195(0.59,2.38)$ \\
\hline Farmer & 2 & 5 & $4.20(0.78,22.52)$ & $3.376(0.59,19.17)$ \\
\hline Daily laborer & 39 & 90 & $3.879(2.30,6.53)$ & $2.73(1.36,5.48) * *$ \\
\hline Other $\#$ & 79 & 47 & 1.00 & 1.00 \\
\hline \multicolumn{5}{|l|}{ Source of Information } \\
\hline Television & 55 & 34 & $0.39(0.19,0.80)$ & $0.3 I(0.14,0.7 I) * *$ \\
\hline Magazine & 17 & 18 & $0.67(0.28, I .6 I)$ & $0.57(0.20,1.56)$ \\
\hline Family & 67 & 85 & $0.80(0.42,1.55)$ & $0.77(0.37,1.65)$ \\
\hline Friends & 19 & 30 & 1.00 & 1.00 \\
\hline \multicolumn{5}{|l|}{ Age } \\
\hline $15-24$ & 17 & 20 & $0.83(0.40,1.75)$ & $0.61(0.19,1.92)$ \\
\hline $25-34$ & 62 & 61 & $0.76(0.35, I .64)$ & $0.49(0.23,1.06)$ \\
\hline $35-44$ & 45 & 40 & I.IS (0.52,2.52) & $0.67(0.32, \mid .4 I)$ \\
\hline$\geq 45$ & 34 & 46 & 1.00 & 1.00 \\
\hline
\end{tabular}

Notes: Other ${ }^{\#}$ (student, housewife); P-value $*<0.05, * *<0.01$.

Abbreviations: COR, crude odds ratio; AOR, adjusted odds ratio.

Daily laborers had a chance of having good knowledge and a favorable attitude towards community-based health insurance. This implies that the more the respondents have good knowledge, the more it is likely to have a favorable attitude towards community-based health insurance. The possible justification for this is daily laborers have no consistent and sustainable income as they receive a fee on the daily basis of the task they perform, and could not earn fees when they get sick. Hence, they would prefer to have an agency that covers the cost for health-care services they utilize when they get ill via paying a certain membership fee annually/biannually to a formal organization. ${ }^{21}$
Those respondents who got information from television were less likely to have better knowledge on CBHI than those who got from friends. This might be because advocacy via television might be costly and might not be frequently disseminated, which in turn might negatively affect their knowledge. This study is similar to previous studies. ${ }^{27}$ In contrast, surprisingly; respondents who got information from television and from family had a favorable attitude. The possible justification for this might be because respondents were suffering from out of pocket health-care utilization, which in fact led them to catastrophic health-care expenses. As a result, they may intend to have a sustainable health service access via health insurance. 
Table 5 Factors Associated with Attitude Towards Community-Based Health Insurance Among Bahir Dar City Informal Workers

\begin{tabular}{|c|c|c|c|c|}
\hline \multirow[t]{2}{*}{ Variables } & \multicolumn{2}{|c|}{ Attitude Towards CBHI } & \multirow[t]{2}{*}{ COR $(95 \% \mathrm{Cl})$} & \multirow[t]{2}{*}{ AOR $(95 \% \mathrm{Cl})$} \\
\hline & Unfavorable & Favorable & & \\
\hline \multicolumn{5}{|l|}{ Sex } \\
\hline Male & 83 & 82 & 1.00 & 1.00 \\
\hline Female & 61 & 99 & $1.64(1.05,2.55)$ & $0.61(0.36,1.03)$ \\
\hline \multicolumn{5}{|l|}{ Education } \\
\hline No formal education & 42 & 21 & $0.31(0.16,00.57)$ & $0.49(0.19,1.21)$ \\
\hline Primary & 30 & 30 & $0.61(0.34,1.13)$ & $0.78(0.34,1.77)$ \\
\hline Secondary & 17 & 41 & $1.49(1.77,2.87)$ & $2.04(1.91,4.56)^{*}$ \\
\hline College and above & 55 & 89 & 1.00 & 1.00 \\
\hline \multicolumn{5}{|l|}{ Marital status } \\
\hline Single & 42 & 50 & $0.34(0.14,0.82)$ & $0.23(0.08,0.67)^{* *}$ \\
\hline Married & 94 & 103 & $0.31(0.13,0.72)$ & $0.29(0.11,0.73)^{* * *}$ \\
\hline Divorced & 8 & 28 & 1.00 & 1.00 \\
\hline \multicolumn{5}{|l|}{ Occupation } \\
\hline Merchant & 30 & 33 & I.33 $(0.73,2.44)$ & $1.16(0.58,2.35)$ \\
\hline Farmer & 1 & 6 & $7.26(0.85,62.1)$ & $3.33(0.59, \mid 8.7 I)$ \\
\hline Daily laborer & 44 & 85 & $2.33(1.41,3.87)$ & $2.84(1.37 .5 .88)^{*}$ \\
\hline Other ${ }^{\#}$ & 69 & 57 & 1.00 & 1.00 \\
\hline \multicolumn{5}{|l|}{ Source of Information } \\
\hline Television & 33 & 56 & $3.500(1.67,7.3)$ & $3.09(1.37,6.93)^{* *}$ \\
\hline Magazine & 18 & 17 & $1.94(0.79,4.75)$ & I.5। $(0.55,4.15)$ \\
\hline Family & 60 & 92 & $3.16(1.60,6.24)$ & $2.63(1.23,5.61)^{*}$ \\
\hline Friends & 33 & 16 & 1.00 & 1.00 \\
\hline \multicolumn{5}{|l|}{ Age } \\
\hline $15-24$ & 11 & 26 & $3.04(1.32,6.98)$ & $\mathrm{I} .85(0.6 \mathrm{I}, 5.59)$ \\
\hline $25-34$ & 49 & 74 & $1.94(1.09,3.43)$ & $0.98(0.48,2.01)$ \\
\hline $35-44$ & 39 & 46 & I.5I $(0.82,2.80)$ & $0.80(0.39,1.65)$ \\
\hline$\geq 45$ & 45 & 35 & 1.00 & 1.00 \\
\hline \multicolumn{5}{|l|}{ Knowledge status } \\
\hline Poor & 62 & 96 & $1.49(0.962,2.32)$ & I \\
\hline Good & 82 & 85 & 1.00 & I \\
\hline
\end{tabular}

Notes: Other ${ }^{\#}$ (student, housewife); P-value $*<0.05, * *<0.01$.

Abbreviations: COR, crude odds ratio; AOR, adjusted odds ratio.

\section{Conclusion and Recommendations}

The knowledge and attitude level of the informal workers towards community-based health insurance is low as per the national standard. The study revealed that $51.4 \%$ of respondents had good knowledge, and 56\% had a favorable attitude towards community-based health insurance. Marital status, occupation, educational status, and source of information were statistically associated with knowledge. While marital status, occupation, and source of information statistically were associated with the attitude towards community-based health insurance. Therefore, Bahir Dar city's health and education offices should extensively advocate community-based health insurance in the health facilities, kebele meetings, schools, and mass media so as to create awareness about community-based health insurance in all informal workers of the city. 


\section{Ethical Consideration}

Ethical approval was obtained from GAMBY College of Medical Sciences, Research and Publication Office. A support letter was obtained from the Bahir Dar City Administrative Office. The college research and publication office approved the procedure for verbal consent as the study is not a sensitive and privacy issue, rather assessing the familiarity and perceptions towards the community-based health insurance. The purpose of the study was explained to the study participants and verbal informed consent was obtained in the Amharic language from them as this study was conducted in accordance with the Declaration of Helsinki. Confidentiality of information was maintained by omitting any personal identifier from the questionnaires. The study participant information sheet was attached on the front page of the questionnaire and before the actual data collection process, the participants were well informed, and the data collection was voluntary based.

\section{Acknowledgments}

We would like to thank our data collectors, the supervisor, the study participants, and the Bahir Dar City Administrative Office for their cooperation and assistance during the data collection.

\section{Author Contributions}

All authors made substantial contributions to conception and design, acquisition of data, or analysis and interpretation of data; took part in drafting the article or revising it critically for important intellectual content; agreed on the journal to which the article will be submitted; gave final approval of the version to be published; and agreed to be accountable for all aspects of the work.

\section{Disclosure}

The authors declare that they have no competing interests.

\section{References}

1. UN S. The Sustainable Development Goals Report. United Nations New York; 2016.

2. Obse A, Hailemariam D, Normand C. Knowledge of and preferences for health insurance among formal sector employees in Addis Ababa: a qualitative study. BMC Health Serv Res. 2015;15:318. doi:10.1186/ s12913-015-0988-8

3. Chapman AR. Assessing the universal health coverage target in the sustainable development goals from a human rights perspective. $B M C$ Int Health Hum Rights. 2016;16(1):33. doi:10.1186/s12914-016-0106-y
4. Wiesmann D, Jütting J. The emerging movement of community based health insurance in sub-Saharan Africa: experiences and lessons learned. Afr Spectrum. 2000;193-210.

5. World Health Organization. Tracking universal health coverage: 2017 global monitoring report. 2017.

6. Kumar P. Providing the providers-remedying Africa's shortage of health care workers. $N$ Engl J Med. 2007;356(25):2564-2567. doi:10.1056/NEJMp078091

7. Kruk ME, Goldmann E, Galea S. Borrowing and selling to pay for health care in low-and middle-income countries. Health Aff. 2009;28 (4):1056-1066. doi:10.1377/hlthaff.28.4.1056

8. Nimpagaritse M, Bertone MP. The sudden removal of user fees: the perspective of a frontline manager in Burundi. Health Policy Plan. 2011;26(suppl 2):ii63-ii71. doi:10.1093/heapol/czr061

9. Acharya A, Ranson MK. Health care financing for the poor: community-based health insurance schemes in Gujarat. Econ Polit Wkly. 2005;4141-4150.

10. Yismaw M. Role of Community Based Health Insurance on Health Service Provision and Healthcare Seeking Behavior of Households in Rural Ethiopia: The Case of Tehuledere District, South Wollo Zone. 2017.

11. Arhinful DK. The Solidarity of Self-Interest: Social and Cultural Feasibility of Rural Health Insurance in Ghana. Leiden: African Studies Centre; 2003.

12. Ethiopian Health Insurance Agency. Evaluation of community-based health insurance pilot schemes in ethiopia: final report. 2015.

13. USAID. Ethiopia Scales. Up Community-Based Health Insurance. Health finance \& governance; 2015.

14. Ekman B. Community-based health insurance in low-income countries: a systematic review of the evidence. Health Policy Plan. 2004;19(5):249-270. doi:10.1093/heapol/czh031

15. Feleke S, Mitiku W, Zelelew H, Ashagari T. Ethiopia's CommunityBased Health Insurance: A Step on the Road to Universal Health Coverage. Washington: World Bank Group; 2015.

16. Lavers T. Towards Universal Health Coverage in Ethiopia's 'developmental state'? The political drivers of health insurance. Soc Sci Med. 2019;228:60-67. doi:10.1016/j.socscimed.2019.03.007

17. Noubiap JJN, Joko WYA, Obama JMN, Bigna JJR. Communitybased health insurance knowledge, concern, preferences, and financial planning for health care among informal sector workers in a health district of Douala, Cameroon. Pan Afr Med J. 2014;16:1.

18. Jembere MY. Attitude of rural households towards community based health insurance in Northeast Ethiopia, the Case of Tehuledere District. Prim Health Care. 2018;8:303. doi:10.4172/2167-1079.1000303

19. Olugbenga-Bello A, Adebimpe W. Knowledge and attitude of civil servants in Osun state, Southwestern Nigeria towards the national health insurance. Niger J Clin Pract. 2010;13:4.

20. Reshmi B, NAIR NS, Sabu K, Unnikrishnan B. Awareness, attitude and their correlates towards health insurance in an urban south Indian population. Manage Health. 2012;16:1.

21. Yusuf H, Kanma-Okafor O, Ladi-Akinyemi T, Eze U, Egwuonwu C, Osibogun A. Health insurance knowledge, attitude and the uptake of community-based health insurance scheme among residents of a suburb in Lagos, Nigeria. West Afr J Med. 2019;36(2):103-111.

22. Al-Eisa IS, Al-Mutar MS, Al-Abduljalil HK. Job satisfaction of primary health care physicians at capital health region, Kuwait. Middle East J Fam Med. 2005;3:3.

23. Coles ME, Heimberg RG, Weiss BD. The public's knowledge and beliefs about obsessive compulsive disorder. Depress Anxiety. 2013;30(8):778-785. doi:10.1002/da.22080

24. Mahmoud S. Association between burden of care and resilience among family caregivers living with schizophrenic patients. IOSR J Nurs Health Sci. 2011;7(2):42-55. 
25. Branch L, Jette A, Evashwick C, Polansky M, Rowe G, Diehr P. Toward understanding elders' health service utilization. J Community Health. 1981;7(2):80-92. doi:10.1007/BF01323227

26. Okobia MN, Bunker CH, Okonofua FE, Osime U. Knowledge, attitude and practice of Nigerian women towards breast cancer: a cross-sectional study. World J Surg Oncol. 2006;4(1):11. doi:10.1186/ 1477-7819-4-11
27. Mirza N, Nisar N, Ikram Z. Knowledge, attitude \& practices towards attention deficit hyperactivity disorder among private elementary school teachers of Karachi, Pakistan. J Dow Univ Health Sci. 2017;11(1):11-17.

\section{Publish your work in this journal}

The International Journal of General Medicine is an international, peer-reviewed open-access journal that focuses on general and internal medicine, pathogenesis, epidemiology, diagnosis, monitoring and treatment protocols. The journal is characterized by the rapid reporting of reviews, original research and clinical studies across all disease areas. The manuscript management system is completely online and includes a very quick and fair peer-review system, which is all easy to use. Visit http://www.dovepress.com/ testimonials.php to read real quotes from published authors.

Submit your manuscript here: https://www.dovepress.com/international-journal-of-general-medicine-journal 